\title{
STRATEGI PROMOSI PENJUALAN ONLINE LAZADA.CO.ID
}

\author{
Faisal Reza*
}

PT. Bank Mandiri (Persero) Tbk

\begin{abstract}
ABSTRAK
Penelitian ini bertujuan untuk mengetahui strategi promosi penjualan melalui media online website yang dilakukan oleh lazada Indonesia. Penelitian ini menggunakan metode studi kasus, pengumpulan data dilakukan melaui wawancara mendalam, observasi dan studi dokumentasi. Subjek penelitiannya adalah pimpinan dan karyawan lazada Indonesia yang berkantor pusat di Menara Bidakara 1 lantai 16 jalan Jend. Gatot Subroto, Jakarta Selatan. Hasil penelitian ini mengungkapkan bahwa strategi promosi penjualan melalui media online website lazada.co.id ini melakukan pemasaran online dengan cara menciptakan website untuk interaksi konsumen dan proses perdagangan elektronik, merancang website yang efektif agar mudah digunakan oleh konsumen, menggunakan email dalam menyebarkan informasi promosi penjualan, dan melakukan promosi penjualan secara online melalui website lazada.co.id. Aktivitas promosi penjualan melaui media online website yang dilakukan lazada Indonesia merupakan suatu bentuk komunikasi terhadap konsumen dalam perdagangan elektronik (e-commerce). Kegiatan aktivitas tersebut diantaranya tahap awal perencanaan, pelaksanaan dan tahap akhir evaluasi. Alat promosi penjualan yang digunakan lazada diantaranya adalah lazada menggunakan alat promosi diskon, voucher, flash sales, special offer from partner, dan melakukan kegiatan pameran dagang. Berdasarakan hasil penelitian dapat ditarik kesimpulan bahwa strategi promosi penjualan yang dilakukan lazada Indonesi melaui media online website merupakan alat promosi penjualan utama yang digunakan lazada Indonesia dalam melakukan perdagangan elektronik (e-commerce).
\end{abstract}

Kata-kata kunci: Pemasaran, Perdagangan elektronik, strategi pemasaran, promosi penjualan, lazada

\section{ONLINE SALES PROMOTION STRATEGY LAZADA.CO.ID}

\section{ABSTRACT}

This study aims to determine the sales promotion strategies through online media websites conducted by lazada Indonesia.This research uses the case study method, data collection is done through in-depth interviews, observation and documentation study. Subject of research is leadership and employees lazada Indonesia headquarters in Menara Bidakara 1 Gen. street 16 floors. Gatot Subroto, South Jakarta. Results of the study revealed that sales promotion strategies through online media lazada.co.id website is doing online marketing by creating a website for consumer interaction and electronic commerce processes, designing an effective website to be easily used by consumers, using email to disseminate information sales promotion, and online sales promotion via the website lazada.co.id. Sales promotion activities through the medium of online websites that do lazada Indonesia is a form of communication to consumers in electronic commerce (e-commerce). The activities of such activities include the early stages of planning, implementation and evaluation of the final stage. Sales promotion tool used lazada include lazada use discount promotion tool, voucher, flash sales, special offer from a partner, and trade show activities. Based on this research can be concluded that the sales promotion strategies that do lazada Indonesi website through online media is a major sales promotion tool used lazada Indonesia in elektronil trade (e-commerce).

Keywords: marketing, e-commerce, marketing strategy, sales promotion, lazada

\footnotetext{
${ }^{*}$ Korespondensi: Faisal Reza, S.Sos., M.I.Kom. PT. Bank Mandiri Tbk Jl. Tanah Abang Timur No.11 Jakarta Pusat 10110. Email: eza_faisal@yahoo.com
} 


\section{PENDAHULUAN}

Lazada.co.id adalah pusat belanja online yang menawarkan berbagai macam jenis produk mulai dari elektronik, buku, mainan anak dan perlengkapan bayi, alat kesehatan dan produk kecantikan, peralatan rumah tangga, dan perlengkapan traveling dan olah raga. Lazada Indonesia didirikan pada tahun 2012 dan merupakan salah satu cabang dari jaringan retail online Lazada.co.id di Asia Tenggara Grup Lazada International di Asia Tenggara terdiri dari Lazada Indonesia, Lazada Malaysia, Lazada Vietnam, Lazada Thailand dan Lazada Filipina. Jaringan Lazada Asia Tenggara merupakan cabang anak perusahaan jaringan perusahaan Internet Jerman, Rocket Internet. Rocket Internet merupakan perusahaan online yang sukses menciptakan perusahaanperusahaan online inovatif di berbagai belahan dunia. Berkantor pusat di Berlin, Jerman, proyek yang dimiliki Rocket Internet antara lain Zalando, TopTarif, eDarling, Groupon dan lain sebagainya. Lazada.co.id Indonesia dapat di akses melalui World Wide Web Lazada.co.id.

Online shopping merupakan salah satu kemudahan dalam gaya hidup modern saat ini. Online shopping menjadi salah satu bukti berkembangnya teknologijaringan komunikasi khususnya Internet di Indonesia sejak beberapa tahun terakhir ini. Berbagai kemudahan dalam berbelanja melalu Internet ini dirasakan oleh pengguna seperti memudahkan dalam pencarian produk, tidak perlu membuang banyak waktu dan tenaga dan banyak lagi kemudahan yang ditawarkan oleh situs-situs online shop. Tentu saja ada pula kelemahan yang terjadi ketika kita berbelanja melalui media online tersebut seperti perbedaan tampilan produk pada website dengan produk yang dikirimkan, lamanya waktu pengiriman, bahkan hingga tidak sampainya barang yang telah dipesan dan dibayarkan. Hal tersebut merupakan beberapa kekhawatiran orang yang muncul ketika berbelanja di situs online. Bagi Lazada.co.id, ini merupakan tantangan untuk meningkatkan kepercayaan dalam berbelanja online.

Berdasarkan perhitungan, Lazada.co.id. merupakan situs nomor 9 yang paling sering di akses di Indonesia dan merupakan situs online shop paling populer dan sering diakses oleh para pengguna Internet di Indonesia dalam perdagangan elektronik (e-commerce) (Alexa, 2016). E-commerce adalah penyebaran, pembelian, penjualan, pemasaran barang dan jasa melalui sistem elektronik, dengan cara transfer dana elektronik (Suyanto, 2003: 10). E-commerce juga merupakan bagian dari e-business, tetapi cakupan e-business lebih luas. E-commerce pertama kali diperkenalkan tahun 1994. Banyak jurnalis memperkirakan bahwa e-commerce akan menjadi sebuah sektor ekonomi baru yang nantinya berkembang pesat.

Kesuksesan Lazada.co.id sampai saat ini didukung dengan sebuah kegiatan pemasaran yang baik sehingga dapat menembus pasar e-commerce di Indonesia yang mempunyai banyak perbedaan budaya. Karakteristik konsumen di Indonesia yang selalu mempertimbangkan nilai dan kegunaan sebuah produk dengan teliti (Soemanagara, 2012: 129), mampu dihadapi oleh Lazada. co.id. Pertumbuhan pesat Lazada.co.id memperlihatkan pangsa pasar e-commerce di Indonesia yang semakin lama semakin berkembang dalam perdagangan melalui media Internet.

Perkembangan teknologi informasi terutama Internet, merupakan faktor pendorong perkembangan e-commerce. Internet merupakan jaringan global yang menyatukan jaringan komputer di seluruh dunia, sehingga memungkinkan terjalin-nya komunikasi dan interaksi antara satu dengan yang lain diseluruh dunia. Dengan menghubungkan jaringan komputer perusahaan dengan Internet, perusahaan dapat menjalin hubungan bisnis dengan rekan bisnis atau konsumen secara lebih efisien. Sampai saat ini Internet merupakan infrastruktur yang ideal untuk menjalankan e-commerce, sehingga istilah e-commerce pun menjadi identik dengan menjalankan bisnis di Internet. Dengan jumlah pengguna Internet yang mencapai angka 82 juta orang atau sekitar $30 \%$ dari total penduduk di Indonesia (Surata, 2015), pasar e-commerce menjadi tambang emas yang sangat menggoda bagi sebagian orang yang bisa melihat potensi kedepannya. Pertumbuhan ini didukung dengan data dari Menkominfo yang menyebutkan bahwa nilai transaksi e-commerce pada tahun 2013 mencapai angka Rp130 triliun. Pasar bisnis 
perdagangan elektronik diperkirakan akan terus tumbuh dengan meningkatnya infrastruktur pendukung Internet di Indonesia. Data dari lembaga riset ICD yang mempunyai kantor pusat di London UK ini memprediksi bahwa pasar e-commerce di Indonesia tumbuh 42\% dari tahun 2012-2015. Angka ini lebih tinggi jika dibandingkan negara lain seperti Malaysia (14\%), Thailand (22\%), dan Filipina (28\%) (Mitra, 2014). Tentulah nilai sebesar ini sangat menggoda bagi sebagian investor, baik dalam maupun luar negeri dalam mengembangkan kegiatan pemasaran melalui media online.

Kegiatan pemasaran wajib dimiliki oleh setiap perusahaan agar dapat terus berkembang. Pemasaran adalah suatu proses sosial dan manajerial yang didalamnya individu dan kelompok mendapatkan apa yang mereka butuhkan dan inginkan dengan menciptakan, menawarkan, dan mempertukarkan produk yang bernilai dengan pihak lain (Kotler, 1997: 8). Setiap perusahaan tentunya memiliki strategi pemasarannya masing-masing. Strategi pemasaran merupakan hal yang penting bagi perusahaan, dimana strategi perusahaan merupakan cara untuk mencapai tujuan dari sebuah perusahaan. Strategi adalah serangkaian rancangan besar yang menggambarkan bagaimana sebuah perusahaan harus beroperasi dalam mencapai tunjuannya (Stanton, 1991: 5). Pemasaran saat ini semakin berkembang dengan adanya perkembangan teknologi yang memudahkan pengguna menggunakan Internet dengan smartphone, tablet dan laptop juga membuat perilaku konsumen yang berubah dan hal ini menjadi peluang baru di dunia pemasaran. Perusahaan dan pemilik brand harus segera menyesuaikan praktek marketingnya dengan berbagai perusahaan yang ada (Kartajaya, 2008: 9).

Komunikasi pemasaran menjadi inti bagaimana perusahaan memanfaatkan sebuah strategi, perencanaan, pelaksanaan dan evaluasi dalam mempertahankan atau mengembangkan perusahaan di dunia bisnis. Pemasaran pada masa sekarang ini tidak cukup hanya dengan pengembangan produk, peningkatan kualitas, penetapan harga yang terjangkau atau penyaluran produk yang tepat, tetapi juga dengan menggunakan media dalam melakukan pemasaran yaitu media online.
Semenjak didirikannya Lazada.co.id pada tahun 2012, perusahaan tersebut telah menjadi salah satu online shop terbesar yang dapat membidik pasar di Indonesia dengan media online. Media online dijadikan sebagai cara dalam membidik pasar dengan melakukan promosi penjualan, melakukan pemasaran, mendapatkan pasar atau konsumen, dan juga alat dalam melakukan hubungan dengan para calon konsumen. Internet terutama website dan sosial media merupakan alat utama dalam menjual produk, selain itu digunakan dalam memberikan informasi penawaran potongan harga dan promo-promo yang sedang berlangsung kepada konsumennya. Hal ini menunjukan begitu kuat pemasaran yang dilakukan melalui Internet saat ini.

Peneliti menemukan bahwa saat ini penggunaan promosi penjualan melalui media Internet sering ditemui dan semakin kreatif dalam mengomunikasikannya kepada konsumen. Alat-alat promosi penjualan yang dilakukan Lazada.co.id di website kepada konsumen mencakup voucher, flash sales, special offers from patner, diskon, pameran dagang (Monday mastercard, I love Wednesday, mobile weekend, Friday frenzy, midnight sale, sale anniversary), dan potongan rabat (cash back).

Meskipun peneliti menyadari bahwa promosi penjualan melalui Internet sudah terjadi dimana-mana, tetapi peneliti merasa bahwa tidak semua perusahaan menggunakan komunikasi pemasaran melalui media Internet sama dan dengan tepat. Proses pembentukan strategi promosi penjualan melaui media online cukup sulit dalam menembus pasar di Indonesia. Begitu banyak perbedaan konsumen di Indonesia mulai dari cara berbelanja, cara mengapresiasi suatu produk, cara melihat promosi penjualan, keadaan ekonomi, perbedaan budaya dan perkembangan teknologi menjadi tantangan tersendiri bagi perusahaan sebesar Lazada.co.id. Hal tersebut yang menarik perhatian peneliti untuk membahasnya lebih jauh dalam kajian ilmiah.

Dari paparan tersebut, menarik untuk diteliti lebih lanjut tentang strategi promosi penjualan Lazada.co.id dalam perkembangannya menjadi salah satu situs perdagangan online terbesar di Indonesia 
dengan tingkat kepercayaan yang tinggi dari konsumen dan efisiensi promosi penjualan yang dilakukan dalam proses pemasaran.

\section{METODE PENELITIAN}

Penelitian ini menggunakan metode kualitatif dengan jenis penelitian studi kasus. Penelitian studi kasus adalah penelitian yang menempatkan sesuatu atau objek yang diteliti sebagai sebuah kasus. Suatu objek diangkat sebagai kasus apabila objek tersebut dipandang sebagai suatu sistem yang dibatasi yang terikat dengan waktu dan tempat kejadian objek.

Studi kasus adalah salah satu metode penelitian ilmu-ilmu sosial. Secara umum, studi kasus merupakan strategi yang lebih cocok bila pokok pertanyaan penelitian berkenaan dengan how (bagaimana) atau why (mengapa) (Yin dalam Wicaksana dan Bajari, 2015). Pertanyaan 'bagaimana' dan 'mengapa' pada dasarnya lebih ekplanatoris dan lebih mengarah pada penggunaan strategi studi kasus, historis, dan eksperimen. Dalam penelitian studi kasus terdapat beberapa hal yang perlu diperhatikan. Berkaitan dengan data penelitian, penelitian studi kasus harus mengumpulkan bukti-bukti dari berbagai sumber baik melalu dokumentasi, observasi, wawancara, maupun survei.

Metode studi kasus digunakan oleh peneliti karena sesuai untuk memaparkan komunikasi pemasaran melalui media online yang dilakukan oleh Lazada.co.id. Tujuan dari penelitian studi kasus adalah untuk mebuat gambaran atau lukisan secara sitematis, aktual dan akurat mengenai fakta-fakta, serta hubungan antara fenomena yang diselidiki. Peneliti membahas secara mendalam komunikasi pemasaran melalui media online yang dilakukan oleh Lazada.co.id dalam melakukan tindakan promosi penjualan terhadap produkproduknya.

Menurut Yin (2012: 23) penelitian studi kasus dibagi menjadi tiga tipe, yaitu: (1) Studi kasus eksploratoris: yaitu kasus diteliti untuk memperoleh informasi awal bagi penelitian sosial yang dilakukan., (2) Studi kasus eksplanatoris: Kasus diteliti untuk memberikan pengetahuan sebab-akibat., (3) Studi kasus deskriptif: Kasus diteliti untuk memberikan gambaran mendalam atau detail mengenai studi kasus tersebut.

Pada penelitian ini, peneliti menggunakan studi kasus eksploratoris. Menurut Yin (2012: 23) penelitian studi kasus eksploratoris yaitu penelitian kasus diteliti untuk memperoleh informasi awal bagi penelitian sosial yang dilakukan. Jenis penelitian yang digunakan yaitu metode single case karena hanya membahas satu kasus secara mendalam.

Untuk meyakinkan atau dapat diterima dalam sebuah penelitian, maka data yang diperoleh harus valid. Aktivitas ini kemudian disebut validitas data. Uji validitas data atau uji keabsahan data dan pemeriksaan terhadap keabsahan data mutlak dilakukan sehingga penelitian benar-benar dapat dipertanggung jawabkan dari segala segi(Moleong, 2006:320). Dalam penelitian kualitatif, untuk memperoleh keabsahan data diperlukan teknik pemeriksaan yang didasarkan atas sejumlah kriteria tertentu. Masing-masing kriteria diperiksa dengan satu atau beberapa teknik pemeriksaan tertentu. Menurut Lincoln dan Guba (dalam Moleong, 2006: 289), pemeriksaan keabsahan data dalam penelitian dilakukan dengan empat derajat, diantaranya; kepercayaan (credibility), keteralihan (transferability), ketergantungan (dependability), dan kepastian (confirmability).

Adapun teknik penelitian yang digunakan dalam penelitian ini meliputi triangulasi sumber data dan member checks. Triangulasi sumber yang dilakukan dengan cara mengecek data yang telah diperoleh melalui beberapa sumber. Dalam hal ini peneliti melakukan pengumpulan dan pengujian data yang telah diperoleh. Kemudian data yang didapatkan dari narasumber dideskripsikan dan dikategorikan mana pandangan yang sama dan mana yang berbeda. Data yang telah dianalisis tersebut akhirnya disimpulkan.

Pada teknik member checks, peneliti melakukan wawancara secara mendalam dengan key informant yang direkam dengan audio recorder selama pengumpulan data. Data tersebut kemudian di transkripsi, dan untuk memastikan akurasi dari data tersebut, peneliti meminta informan untuk membaca transkripsi tersebut guna memastikan apa yang dimaksud oleh informan sesuai dengan yang tertulis dalam transkrip wawancara. 


\section{HASIL DAN PEMBAHASAN}

Sebagian besar bisnis online lazada Indonesiasaatinidilaksanakandijaringandigital yang menghubungkan lazada dengan konsumen melalui media website yang terhubung dengan Internet. Internet adalah jaringan komputer yang menghubungkan pengguna di seluruh dunia dengan menghubungkan mereka dengan "penyimpanan informasi" yang sangat besar (Kotler \& Armstrong, 2008: 237). Internet merupakan sebuah media komunikasi pemasaran dimana konsumen dapat berinteraksi dengan toko online yang berusaha memberikan penawaran kepada mereka. Konsumen dapat berinteraksi dengan mudah melalui media Internet ini. Mereka dapat secara langsung mengontrol pesanan ataupun permintaan informasi lebih lanjut. Demikian pula yang dilakukan lazada Indonesia untuk dapat menciptakan nilai bagi pelanggan dan membangun hubungan dengan pelanggan melalui Internet yang telah memberikan pemasar dengan cara yang benar-benar baru. Melalui media website, lazada Indonesia memberikan informasi lebih mendalam dan leluasa mengenai bentuk serta manfaat suatu produk. Hal ini lebih menguntungkan pemasar dibandingkan menggunakan media lain dimana pemasar harus mengeluarkan biaya yang cukup besar untuk iklan.

Internet mengubah sifat dasar dari standar komunikasi pemasaran seperti periklanan dan promosi penjualan. Dalam hal ini, website serupa fungsinya dengan iklan dan merupakan media penjualan baru karena mampu memberikan informasi, bujukan, mengingatkan konsumen mengenai penawaran produk dan melakukan transaksi perdagangan elektronik (e-commerce). Suyanto (2003) mengemukakan e-commerce merupakan konsep baru yang bisa digambarkan sebagai proses jual beli barang atau jasa pada world wide web Internet atau proses jual beli atau pertukaran produk, jasa dan informasi melalui jaringan informasi termasuk Internet. Dengan kata lain, website dianggap perpaduan antara periklanan dan penjualan langsung karena media ini juga dapat mengajak pengunjungnya dalam sebuah dialog atau interaksi langsung.

Model perdagangan elektronik yang dilakukan lazada Indonesia ada 2 klasifikasi yaitu pertama adalah bussiness to consumer (B2C) menjual barang dan jasa secara online kepada konsumen akhir (Kotler \& Armstrong, 2008: 238). Konsumen saat ini hampir bisa membeli segala hal secara online di website lazada Indonesia, mulai dari barang elektronik, pakaian, peralatan memasak, perlengkapan bayi, aksesoris dan lain sebagainya. Kedua, bussiness to bussines (B2B) lazada Indonesia melakukanbisnisonline inibekerjasamadengan perusahaan lain seperti perusahaan elektronik yang akan meluncurkan produk terbaru mereka dan menjualnya melaui lazada Indonesia, kegiatan ini memberikan keuntungan ekonomi terhadap kedua pihak. Dengan menggunakan $\mathrm{B} 2 \mathrm{~B}$ ini jaringan perdagangan online dapat menjangkau pelanggan bisnis baru, melayani pelanggan lebih efektif, dan meraih efisiensi pembelian dan harga yang lebih baik (Kotler \& Armstrong, 2008: 239).

Komunikasi lewat media Internet berbeda dengan komunikasi pemasaran media tradisional. Perubahan gaya komunikasi dengan lebih segera, melalui email, dimana terdapat two way interaction antara penjual dan pembeli, waktu pengiriman serta penerimaan informasi oleh keduanya dapat diukur dalam hitungan detik sehingga ada keselarasan komunikasi. Ini merupakan teknologi web 2.0 yang sudah merubah segalanya. Internet saat ini menjadi bersifat interaktif dan dinamis. Seseorang lebih mudah mengekspresikan dirinya, melakukan networking, membentuk komunitas, berkolaborasi, berpartisipasi, dan banyak hal lainnya (Kartajaya, 2008: 6). Era yang disebut oleh Hermawan Kartajaya sebagai Era New Wave (web 2.0) menjadikan manusia memasuki tahap perkembangan menjadi pekerja kreatif. Teknologi mendorong lahirnya kreativitas dan mendorong tumbuhnya partisipasi masyarakat. Di era partisipasi alias Era New Wave Marketing, yang terpenting adalah sebuah akses yang terbentuk melalui jaringan yang saling berbagi dan berinteraksi (Kartajaya, 2008: 156). Interaksi langsung seperti halnya melalui Internet ini membuat proses pemasaran ke konsumen lebih terasa akrab, aktif dan personal.

Meskipun demikian, Internet tidak sepenuhnya dapat menjamin hubungan utama antara pengirim dan penerima informasi. Ada beberapa hal yang menentukan efektivitas 
pemasaran melalui Internet, yaitu desain dan pengembangan website yang merupakan orientasi utama lazada Indonesia untuk menyampaikan pesan terkait informasi produk yang ingin disampaikan ke konsumen, dan lazada Indonesia tidak spesifik ditujukan pada pasar tertentu, jadi siapa saja bisa memanfaatkannya untuk memperoleh informasi tertentu.

Kotler \& Armstrong (2008) menjelaskan bahwa perilaku pembelian konsumen sangat dipengaruhi oleh karakteristik personal. Kebudayaan, kelompok sosial, ekonomi maupun faktor psikologis sangat memengaruhi respon mereka terhadap pesan pemasaran. Di sini Internet berperan sebagai media yang dapat menampung berbagai konsumen dengan beragam latar belakang sosial dan kebudayaan. Hal ini menjadi keunggulan bagi lazada Indonesia dengan banyaknya potensial konsumen dari berbagai daerah di Indonesia yang dapat memperluas pemasaran produkproduk yang ditawarkan oleh lazada Indonesia melalui website.

Lazada Indonesia tidak menentukan segmentasi pasar yang terperinci. Mereka menargetkan pasar konsumen yang menggunakan atau terhubung langsung dengan jaringan Internet siapa pun dan dimana saja melaui media online website. Lazada Indonesia melihat pasar dari 3 faktor diantaranya yaitu lingkungan ekonomi, lingkungan budaya, dan lingkungan teknologi. Dilihat dari lingkungan ekonomi, suatu pasar tentunya memerlukan adanya daya beli. Daya beli yang tersedia dalam suatu perekonomian bergantung pada pendapatan, harga, tabungan dan ketersedian kredit. Pemasar harus dapat memperhatikan dengan cermat trend utama dalam pendapatan dan pola pembelanjaan konsumen (Kotler, 1997: 138). Lazada Indonesia melihat potensi yang besar di Indonesia yang ditunjukan data dari Menkominfo yang menyebutkan bahwa nilai transaksi e-commerce pada tahun 2013 mencapai angka Rp130 triliun. Hal ini merupakan potensi yang besar bagi dunia perdagangan elektronik di Indonesia.

Lingkungan budaya menunjukkan bahwa setiap orang memiliki perilaku yang berbeda di masyarakat. Manusia menyerap hampir secara tidak sadar, pandangan dunia yang merumuskan hubungan mereka dengan dirinya sendiri dan sesamanya. Kelompokkelompok yang memiliki nilai yang sama dengan para konsumen akan mempengaruhi mereka dalam pembelian barang (Kotler, 1997: 148). Keanekaragaman budaya, letak geografis, dan karakteristik orang Indonesia memang menentukan ketika melakukan belanja. Tantangan yang dihadapi lazada Indonesia ini mereka bangun kepercayaan untuk melakukan belanja di situs web lazada.co.id dengan meningkatkan fasilitas layanan, ketika orang membeli sebuah produk menginginkan barang tersebut ada terlebih dahulu lazada menyediakan fasilitas cash on delivery, dimana barang yang akan dibeli konsumen langsung diantarkan dan dibayar di tempat dan lazada memfasilitasi mereka yang telah berbelanja online dengan customer service untuk keluhan atau penukaran barang yang rusak saat diterima oleh konsumen. Fasilitas customer service tersedia langsung di website lazada.co.id.

Lingkungan teknologi merupakan salah satu kekuatan yang paling besar dalam membentuk hidup manusia adalah teknologi. Perubahan teknologi yang terjadi semakin cepat dan tidak terduga. Para pemasar dituntut untuk mengamati perubahan teknologi yang ada demi mendukung berkembangnya suatu brand (Kotler, 1997: 140). Perkembangan teknologi saat ini sangat pesat, dengan menggunakan website lazada Indonesia sudah bisa melakukan promosi penjualan dan menfasilitasi konsumen dalam berbelanja online dengan berbagai macam fasilitas pembayaran yang diantaranya menggunakan kartu kredit, bank transfer, Internet banking sebagai media pembayaran dalam melakukan perdagangan elektronik (e-commerce). Jelas ini memudahkan konsumen dalam berbelanja dimana pun mereka berada dan terhubung jaringan Internet dengan menggunaka komputer, tablet atau smartphone yang mereka punya.

Peran website lazada Indonesia di sini adalah menyediakan media untuk membantu konsumen yang secara aktif mencari produk kebutuhannya. Di sisi lain, ini merupakan kesempatan bagi lazada Indonesia untuk memberikan deskripsi produk mereka, serta mengajukan penawaran kepada konsumen. Selain itu, lazada Indonesia memfasilitasi website mereka dengan fitur pembayaran yang dapat digunakan oleh konsumen 
untuk bertransaksi melaui kartu kredit, bank transfer dan Internet banking yang memenuhi standar keamanan dan dilengkapi dengan pilihan lain yaitu cash on delivery dimana pengguna membayar tunai produk ketika barang sudah di tangan mereka.

Lazada Indonesia mengakui Internet merupakan media yang potensial untuk mempertahankan konsumen dalam pemasaran online. Pemasaran elektronik adalah sisi perdagangan dari perdagangan elektronik, yang terdiri dari usaha perusahaan untuk mengkomunikasiskan, mempromosikan dan menjual barang dan jasa melalui Internet (Kotler \& Armstrong, 1996: 74). Perbaikan desain atau bentuk serta peningkatan layanan konsumen yang dilakukan oleh website lazada Indonesia, akan mendorong kunjungan yang berkelanjutan oleh konsumen. Kunjungan berulang memberikan kesempatan untuk melakukan penjualan silang dan penjualan berulang melalui promosi penjualan yang ada di laman website lazada.co.id. Jelas, semua perusahaan harus mempertimbangkan untuk bergerak ke online (Kotler \& Armstrong, 2006: 144). Tahapan lazada Indonesia dalam menjalankan pemasaran online melalui website antara lain: mendeskripsikan brand, produk, dan konsumen; menentukan dan merencanakan goals; merancang situs web yang efektif, merancang kegiatan promosi, memanfaatkan email untuk komunikasi dua arah, dan evaluasi.

Lazada Indonesia merupakan salah satu online shop terbesar di Indonesia yang menawarkan beragam produk seperti dari elektronik,buku,mainananakdanperlengkapan bayi, alat kesehatan dan produk kecantikan, peralatan rumah tangga, dan perlengkapan traveling dan olah raga. Banyaknya produk tersebut mendorong lazada dalam melakukan kegiatan promosi penjualan yang kreatif. Lazada membangun pemasaran online dengan menciptakan situs web pemasaran untuk melakukan promosi penjualan produk mereka. Situs web pemasaran adalah situs web yang melibatkan konsumen dalam interaksi yang akan menggerakan mereka lebih dekat ke pembelian langsung atau hasil pemasaran lainnya (Kotler \& Armstrong, 2008: 245).

Situs web ini berfungsi melibatkan konsumen dalam interaksi yang menggerakan mereka lebih dekat dengan pembelian langsung, dalam menciptakan situs web lazada Indonesia merancang situs web yang atraktif dan membuat konsumen mengunjungi situs website mereka dan kembali lagi untuk melakukan transaksi. Situs web lazada Indonesia mempunyai tujuan dan isi yang sangat beragam. Selain menawarkan produk dan membuat promosi penjualan situs lazada Indonesia dirancang untuk membangun hubungan baik dengan pelanggan dengan menawarkan beragam informasi yang kaya dan fitur lain dalam usaha untuk menjawab pertanyaan pelanggan, membangun hubungan pelanggan yang lebih erat dan menghasilkan ketertarikan terhadap perusahaan.

Situs website lazada Indonesia melibatkan konsumen dalam berinteraksi, konsumen bisa menelusuri kategori-kategori produk yang ada di laman lazada Indonesia, konsumen juga dapat melihat informasi produk yang akan mereka beli, selain itu konsumen juga bisa melihat promosi penjualan apa yang sedang berlangsung setiap harinya, dengan melakukan beberapa klik di mouse pengunjung sudah bisa menempatkan pesanan secara online dan menentukan cara pembayarannya, website lazada ini diciptakan untuk kemudahan konsumen dalam melakukan transaksi elektronik di website lazada Indonesia.

Tahapan selanjutnya dalam menciptakan pemasaran online yang dilakukan lazada Indonesia di website adalah merancang situs web yang efektif. Menciptakan situs web adalah langkah awal untuk melakukan kegiatan pemasaran online dan dengan merancang situs website yang efektif dapat menarik pengunjung. Lazada Indonesia secara agresif mempromosikan situs web mereka di iklan televisi, iklan media cetak, iklan afiliasi situs web lain dan di media sosial. Tetapi pengguna website masa kini dengan cepat mengabaikan situs web yang tidak mengikuti perkembangan zaman. Lazada Indonesia menciptakan nilai dan daya tarik yang cukup agar konsumen yang mengunjungi situs tetap tinggal dan kembali lagi untuk melakukan pembelian. Lazada Indonesia dalam hal ini terus memperbaharui situs mereka untuk membuat situs tersebut selalu up to date, baru dan segar.

Tantangan utama lazada Indonesia adalah dengan merancang situs web yang atraktif pada pandangan pertama dan cukup menarik untuk mendorong kunjungan ulang. 
Lazada Indonesia menciptakan situs web ini dengan menata produk mereka sesuai dengan kategori dan menempatkan promosi penjualan yang sedang berlangsung di halaman depan paling atas mereka untuk secara langsung dapat di lihat oleh konsumen disaat menelusuri laman lazada.co.id.

Lazada Indonesia sebagai pelaku pemasaran online memperhatikan rancangan situs yang efektif, yaitu tata letak dan rancangan situs yang didesain untuk memudahkan pengunjung mengakses informasi produk dan informasi promosi penjualan yang sedang berlangsung yang dilengkapi dengan konten gambar dan teks yang menjadi isi situs web lazada Indonesia. Pemasaran online memungkinkan pengguna melakukan komunikasi dua arah. Selain itu, dengan kapabilitas situs untuk melakukan transaksi perdagangan elektronik membuat lazada Indonesia dapat melakukan perubahan yang konstan mengikuti selera konsumen.

Email telah mengemuka sebagai sarana pemasaran online yang penting (Kotler \& Armstrong, 2008: 250). Email dapat digunakan secara reguler untuk memberikan informasi produk baru, di samping sebagai media promosi penjualan. Hal ini mendorong konsumen untuk mengunjungi kembali website lazada. co.id. Lazada menggunakan email untuk menginformasikan kepada konsumen tentang promosi penjualan terbaru mereka atau tentang produk terbaru lazada Indonesia kepada email personal konsumen tetap dan potensial.

Agar tidak menggangu konsumen dengan mengirimkan email pemasaran yang tidak diinginkan, lazada meminta izin kepada konsumen untuk menawarkan pemasaran melalui email. Konsumen diberi pilihan jika ingin mendapatkan informasi melalui email tersebut mereka harus mendaftarkan email mereka terlebih dahulu agar mendapatkan informasi promosi penjualan lazada Indonesia. Pendekatan ini, yang dikenal sebagai pemasaran berdasarkan izin, telah menjadi model standar pemasaran email.

Berawal dari bulan maret 2012 website lazada.co.id diluncurkan di Indonesia. Tidak pernah terpikirkan oleh lazada Indonesia untuk membuat sebuah toko fisik, lazada Indonesia fokus terhadap toko online mereka karena antusias masyarakat Indonesia yang mendambakan kepraktisan dalam berbelanja.
Untuk itu lazada Indonesia melakukan promosi penjualan secara online melalui website.

Promosi penjualan dilakukan melaui website untuk menginformasikan serta memperdagangkan produk-produk yang dimiliki lazada Indonesia. Promosi penjualan melalui media online website ini pun bisa dibilang promosi dengan biaya murah, karena tidak memerlukan biaya-biaya seperti sewa gedung untuk melakukan kegiatan pameran dagang, sales promotion girl, dan lain sebagainya.

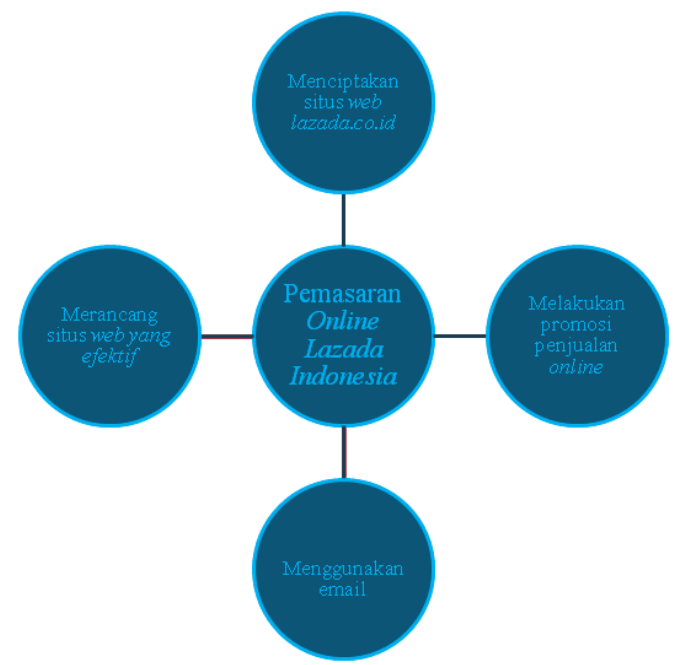

Diagram 1 Strategi Pemasaran Online Lazada
Indonesia

Sumber: hasil penelitian, 2015

Promosi penjualan adalah semua kegiatan pemasaran yang mencoba merangsang terjadinya aksi pembelian suatu produk yang cepat atau terjadinya pembelian dalam waktu singkat. Kegiatan ini mencakup pengertian bagaimana sebuah situs dapat membuat pengunjung kembali. Banyaknya kunjungan ulang yang dilakukan konsumen pada sebuah situs adalah salah satu ukuran untuk melihat seberapa baik situs perusahaan untuk dijadikan media penjualan. Perusahaan menggunakan alat-alat promosi penjualan untuk menciptakan tanggapan yang lebih kuat dan cepat. Promosi penjualan dapat digunakan untuk menarik perhatian dan biasanya memberikan informasi yang dapat mengarahkan konsumen agar melakukan transaksi pembelian. Alat-alat promosi penjualan lazada Indonesia terdiri dari diskon, voucher, special offer from partner, flash sale dan pameran dagang.

Dalam melakukan kegiatan promosi penjualan melalui website lazada Indonesia memiliki tujuan yang ingin dicapai, yaitu meningkatkan 
penjualan setinggi-tingginya. Penetapan tujuan dalam melakukan promosi penjualan lazada Indonesia di website yaitu dengan melakukan tahap awal perencanaan. Kegiatan perencanaan promosi penjualan melalui website yang dilakukan oleh lazada Indonesia dimulai dua hingga satu minggu sebelum kegiatan promosi dilaksanakan. Hal tersebut dilakukan agar kegiatan promosi penjualan berjalan sesuai dengan tujuan yang telah ditetapkan. Perencanaan promosi pen-jualan melalui website ini dilakukan ketika semua perencanaan mencapai final dan dapat di publikasikan di website agar informasi tersebut sampai ke konsumen. Kegiatan promosi penjualan yang dilakukan lazada Indonesia memang harus selalu up to date, karena setiap harinya selalu ada penawaran yangberbeda-beda.

Tahapan selanjutnya dari kegiatan perencanaan promosi penjualan melalui website yang dilakukan oleh lazada Indonesia adalah meeting. Meeting dilakukan untuk membicarakan mengenai seluruh hal yang berkaitan dengan program promosi penjualan yang akan dilaksanakan dalam waktu dekat. Meeting yang dilakukan lazada Indonesia dalam perencanaan launching program promosi penjualan dilaksanakan dua kali sehari, yaitu pertama dengan bagian marketing and business development lazada Indonesia dan yang kedua meeting bersama tim digital online marketing lazada Indonesia. Meeting pertama kali membicarakan program promosi penjualan apa yang akan dilakukan dalam waktu dekat. Setelah meeting pertama kali dengan seluruh tim marketing and business development lazada Indonesia, meeting kedua dilakukan bersama tim online marketing lazada Indonesia untuk membahas bagaimana perencanaan yang akan dilakukan. Setelah meeting dilaksanakan, tim marketing membuat perencanaan tentang promosi penjualan yang nantinya dipresentasikan kembali di sebuah meeting dengan tim online marketing lazada Indonesia untuk di terbitkan di laman website lazada.co.id. Perencanaan promosi merupakan acuan yanag akan dilakukan oleh tim online marketing lazada Indonesia dalam suatu kegiatan promosi penjualan. Perencanaan promosi penjualan didasari oleh tujuan dari perdagangan online lazada Indonsia untuk meningkatkan penjualan perusahaan.
Tim digital online marketing lazada Indonesia menyiapkan perencanaan dalam bentuk gambar, teks, dan desain untuk dipresentasikan di dalam meeting. Pesan tersebut berupa simbol atau lambang yang digunakan untuk menyampaikan pesan promosi penjualan. Lambang meliputi katakata (pesan verbal), perilaku nonverbal, dan objek yang disepakati bersama (Mulyana, 2002: 84). Didalam tim digital online marketing lazada Indonesia terdapat beberapa bagian diantaranya adalah bagian social media online marketing, content marketing, affiliate key account, graphic designer dan customer service.

Promosi penjualan merupakan alat perangsang jangka pendek yang direncanakan untuk merangsang pasar konsumen, perdagangan dan para wraniaga (Suyanto, 2003: 195). Dalam kegiatan promosi penjualannya melalui website, lazada Indonesia: 1. Menggunakan Alat Promosi Diskon, 2. Menyebarkan Alat Promosi Voucher, 3. Flash Sales, 4. Special Offer From Partner, 5. Melakukan Kegiatan Pameran Dagang (Sale Anniversary, Monday Mastercard, I Love Wednesday, Mobile Weekend, Friday Frenzy, dan Peluncuran Poroduk Terbaru). Alat promosi yang dilaksanakan lazada tersebut adalah 10 besar pencapaian penjualan lazada Indonesia ketika berlangsungnya promosi penjualan. Kegiatan promosi penjualan seperti ini banyak ditunggu oleh konsumen ketika mereka ingin mengincar barang terbaru dengan harga yang lebih murah. Lazada Indonesia selalu bekerja sama dengan produk elektronik yang akan meluncurkan produk terbaru mereka. Kegiatan ini dapat dengan cepat meningkatkan penjualan dengan singkat dan efektif untuk mendongkrak hasil penjualan lazada Indonesia.

Setelah semua kegiatan promosi penjualan dilaksanakan, tahap selanjutnya adalah melakukan kegiatan evaluasi dengan melihat hasil pencapaian yang telah di laksanakan selama promosi penjualan. Kegiatan ini dilaksanakan untuk mengetahui apakah tujuan dari promosi penjualan sudah tercapai dan juga apakah terdapat kesalahan dan kekurangan dalam pelaksanaan strategi tersebut. Evaluasi di lakukan oleh tim online marketing lazada Indonesia karena mulai dari tahap perencanaa dan evaluasi yang melakukan tim online 
marketing lazada Indonesia, sehingga di sini tim online marketing lazada Indonesia yang mengerti strategi promosi penjualan yang dilaksanakan sudah sesuai atau tidak. Didalam tahapan evaluasi hal yang perlu diperhatikan adalah standar ukuran yang digunakan untuk dijadikan suatu pedoman evaluasi. Tahapan evaluasi yang dilakukan tim online marketing lazada Indonesia belom memiliki standar yang baku dalam mengevaluasi pelaksanaan strategi promosi penjualan lazada Indonesia. Hanya berupa laporan tertulis hasil penjualan selama pelaksanaan promosi penjualan berlangsung.

Setelah seluruh proses evaluasi strategi promosi penjualan melalui website dilaksanakan, terdapat hasil dari tahapan evaluasi. Hasil evaluasi strategi promosi penjualan melalui website yang dilakukan oleh lazada Indonesia hanyalah sebagai pembelajaran untuk tidak mengulangi kesalahan yang sama dan untuk memperbaiki kegiatan promosi penjualan yang akan diadakan selanjutnya. Evaluasi kegiatan promosi penjualan lazada Indonesia melalui website belum memiliki hasil laporan tertulis yang terperinci. Hasil evaluasi kegiatan promosi penjualan lazada Indonesia melalui website hanya sebagai informasi bagi tim online marketing lazada Indonesia tentang hasil penjualan selama masa promosi penjualan dilaksanakan.

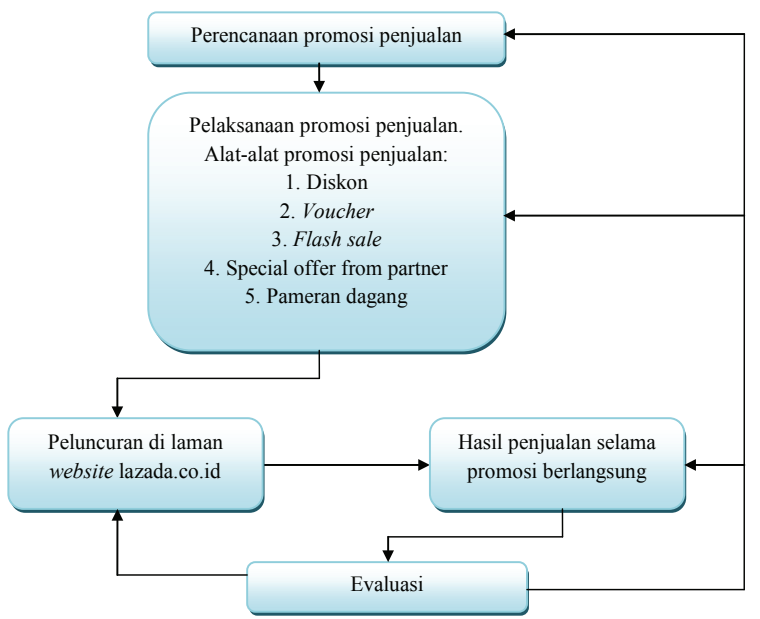

Model 2 Strategi Promosi Penjualan Lazada Indonesia Melalui Website

Sumber: hasil penelitian, 2015

\section{SIMPULAN}

Media online website sebagai strategi promosi penjualan produk lazada.co.id. Dalam menciptakan pemasaran online untuk melakukan promosi penjualan lazada
Indonesia melakukan beberapa hal sebagai berikut: (1) Lazada Indonesia menciptakan website untuk memfasilitasi perdagangan elektronik (e-commerce) yang didalam website tersebut terdapat alat pembayaran yang sudah mempunyai standar keamanan. (2) Merancang situs web yang efektif, yaitu tata letak dan rancangan situs lazada Indonesia didesain untuk memudahkan pengunjung dalam mengakses informasi produk atau informasi promosi penjualan yang sedang berlangsung yang dilengkapi dengan konten gambar dan teks. Hal ini merupakan faktor kemudahan pengguna (ease of use) dalam melakukan transaksi di lazada.co.id. (3) Menggunakan email dalam memberikan informasi penawaran yang dilakukan lazada Indonesia kepada para konsumen. (4) Melakukan promosi penjualan secara online melalui website Aktivitas promosi penjualan melalui media online website yang dilakukan oleh lazada Indonesia yaitu dengan melakukan tahap-tahap sebagai berikut: (1) Tahap awal perencanaan. (2) Pelaksanaan, meluncurkan program promosi penjualan di halaman website lazada. co.id. (3) Melakukan evaluasi kegiatan promosi penjualan.

Berbagai macam alat promosi penjualan melalui media online website seperti diskon, voucher, flash sales, special offer from partner, dan pameran dagang yang dilakukan lazada Indonesia dapat meningkatkan penjualan produk-produk mereka dalam waktu singkat. Alat promosi penjualan ini bermanfaat dalam proses komunikasi bahwa promosi penjualan mampu menarik perhatian, memberi informasi yang memperkenalkan pelanggan terhadap produk dan dapat merangsang atau mendorong konsumen untuk melakukan transaksi di lazada Indonesia. Selain itu promosi penjualan yang dilakukan lazada Indonesia melalu media online website ini tidak memerlukan biaya yang besar.

Saran peneliti berdasarkan hasil penelitian ini yaitu strategi promosi penjualan melalui media online website lazada Indonesia sebaiknya mengikuti secara berkesinambungan perkembangan zaman di era modern ini dimana teknologi berkembang dengan pesat. Hendaknya konsep teknologi ini juga memberikan keamanan saat berbelanja di website lazada.co.id agar 
kepercayaan konsumen meningkat dalam melakukan transaksi elektronik (e-commerce). Selain itu, kegiatan promosi penjualan yang dilakukan lazada Indonesia dalam meningkatkan pengunjung dan transaki penjualan hendaknya dijadikan sebuah siklus yang tidak boleh berhenti. Jika perlu buatkan standar event yang harus dilakukan oleh perusahaan agar konsumen tahu dan selalu menunggu kegiatan promosi penjualan yang akan dilaksanakan.

\section{DAFTAR PUSTAKA}

Alexa. (2016). Top sites in Indonesia. Diakses dari http://alexa.com tanggal 30 Januari 2015.

Creswell, J.W. (2002). Qualitative Inquiry and research design: choosing among five tradition. Thousand: Sage Publication

Kartajaya, H. (2008). New wave marketing. Jakarta: Gramedia Pustaka Utama.

Kotler, P. (1997). Manajemen pemasaran, Alibahasa, Hendra Teguh, Ronny Antonius Rusli. Jakarta: Prenhallindo.

Kotler, P. \& Armstrong, G. (2008). Prinsipprinsip pemasaran jilid 1 edisi keduabelas terjemahan. Jakarta: Erlangga.

Kotler, P. \& Armstrong, G. (2006). Prinsipprinsip pemasaran. Jakarta: Erlangga.

Mitra, W. (2014). Data statistik mengenai pertumbuhanpangsapasare-commerce di indonesia saat ini. Diakses dari http://startupbisnis.com/data-statistikmengenai-pertumbuhan-pangsa-pasar- e-commerce-di-indonesia-saat-ini/ tanggal 12 Februari 2015

Moleong, L. J. (2006). Metode penelitian kualitatif. Bandung: RemajaRosdaKarya.

Mulyana, D. (2002). Metodologi penelitian kualitatif: paradigma ilmu komunikasi dan ilmu sosial lainnya. Bandung: Rosdakarya.

Soemanagara, Rd. (2012). Strategic marketing communication: konsep strategis dan terapan. Bandung: Alfabeta.

Stanton, J. (1991). Prinsip pemasaran, alih bahasa wilhelmus w. bokowatun. Jakarta: Erlangga.

Surata, I, N. (2015). Fantastis, pertumbuhan e-commerce di indonesia saat ini. Diakses dari http://www. academia.edu/12166388/Fantastis Pertumbuhan_E-Commerce_di Indonesia_Saat_īni tanggal 12 Februari 2015

Suyanto, M. (2003). Strategi periklanan pada e-commerce perusahaan top dunia. Yogyakarta: AdiOffset.

Thurlow, C. (2004). Computer mediated communication, social interaction and the internet. London: Sage Publications

Wicaksana, R. R. \& Bajari, A. (2015). Kampanye produk minuman kesehatan melalui games interaktif. Diakses dari http://journal.unpad.ac.id/jkk/article/ view/7397/340129 April 2016

Yin, K. (2012). Studi kasus: desain dan metode. Jakarta: Rajawali Pers. 